\title{
The Japanese Encounter with the South: \\ Japanese Tourists in Palau
}

\section{Shinji Yamashita}

Tourism is a primary ground for the production of new cultural forms on a global base. In the name of tourism, capital and modernized peoples have been deployed to the most remote regions of the world, farther than any army was ever sent. Institutions have been established to support this deployment, not just hotels, restaurants, and transportation systems, but restorations of ancient shrines, development of local handicrafts for sale to tourists. In short, tourism is not just an aggregate of mere commercial activities; it is also an ideological framing of history, nature, and tradition; a framing that has the power to reshape culture and nature to its own needs.

Dean MacCannell, Empty Meeting Grounds

$M_{\text {acCannell's view is relevant to the study of tourism in the age of }}$ global mobility. However, as Okpyo Moon has pointed out, one must be careful about the local situation in a particular context. By looking at Japanese tourists in Korea, Moon demonstrated that the nature of the hostguest relationship and the cultural implications of tourism, which are the central issues of the anthropological study of tourism (Smith 1989), vary depending on who travels, and where (Moon 1997, I78).

Focusing on Palau, a small newly independent Micronesian republic that is attempting to develop itself through tourism, this paper examines the sociocultural implications of Palauan tourism, particularly through the lens of Japanese tourists. It examines them in both the contemporary and the historical contexts, since Japan colonized Micronesia from I9I9 to I945, and Japanese tourism in Palau cannot be fully understood without referring to this historical background. By examining the Japanese

The Contemporary Pacific, Volume I2, Number 2, Fall 2000, 437-463

(C) 2000 by University of Hawai $i$ Press 
encounter with Palau in this way, the paper attempts to contribute to the ongoing teaching and research project, Moving Cultures: Remaking AsiaPacific Studies, the aim of which is to create a new space for dynamic area studies.

\section{The General Features of Tourism in Palau}

Over the last two decades in Palau the number of tourists has steadily increased, from 5,640 in 1980 to 73,719 in 1997 . The increase in the number of tourists is significant in that it is now more than four times Palau's total population of about I7,000. Economically, the contribution of the tourism sector to Palau's gross domestic product today is estimated to be as high as \$I 2 million, which is around I I percent of the total (Palau Government I996, 8-2).

The focus of tourism in Palau is its world famous coral reefs. In I996 approximately 60 percent of the visitors came to Palau for diving (Khaleghi I996, 2I). Palau tourism, then, can be primarily characterized as "ecological nature tourism" (Graburn I989, 32). In this context the Palauan government, aware of the damage that can be caused to the fragile ecosystem by the rapidly growing number of visitors, now emphasizes ecotourism in its scheme of sustainable development. According to Palau 2020: National Master Development Plan, "the low-in-number high quality-high cost establishments, in many ways, seem more suited to the ecosystem (Palau Government I996, 8-I). "Ecotourism" and "sustainable development" are key words for Palau tourism today, and the Palau Vis-

Table I. Visitor arrivals in Palau, I980-I997.

\begin{tabular}{rrrrrr}
\hline Year & Number & Year & Number & Year & Number \\
\hline 1980 & 5,640 & 1986 & 9,612 & 1992 & 36,117 \\
1981 & 5,057 & 1987 & 11,682 & 1993 & 40,497 \\
1982 & 5,330 & 1988 & 15,975 & 1994 & 44,073 \\
1983 & 6,338 & 1989 & 19,396 & 1995 & 53,229 \\
1984 & 9,014 & 1990 & 23,398 & 1996 & 69,330 \\
1985 & 13,371 & 1991 & 32,846 & 1997 & 73,719 \\
\hline
\end{tabular}

Source: Palau Visitors Authority. 
itors Authority compiled a policy document, Sustainable Development Policies and Action Plan, in May 1997. During my field research in March I998, the Palau Visitors Authority held a weeklong workshop to further review their action plan. The theme for the 1997 tourism awareness week was Tourism: Balancing between Nature and \$ense, with \$ense representing the economic benefits of the industry.

Of the total of 73,719 visitors in 1997, 31,246 were from Taiwan, 20,507 from Japan, and I0,48I from the United States, to mention the top three countries of origin. Asia, particularly Taiwan and Japan, is thus the most important market for Palau tourism, as the visitors from these two countries constitute about 70 percent of the total visitors to Palau. The number of Taiwanese visitors has increased rapidly in recent years. In I996 Taiwan ranked first, surpassing the number of visitors from Japan, formerly the dominant source. The rapid growth in Taiwanese tourists was facilitated by the introduction of a daily direct flight between Taiwan and Palau in 1996 (Tia Belau, I4-21 Dec 1996).

Japanese, Taiwanese, and Americans are the three major visitor groups in Palau. There are differences in behavior patterns according to the nationality of the tourists. In its research, the Pacific Business Center Program observed these differences:

Table 2. Visitor arrivals in Palau, I992-1997, by nationality

\begin{tabular}{lrrrrrr}
\hline Nationality & 1992 & 1993 & 1994 & 1995 & 1996 & 1997 \\
\hline Japan & 17,021 & 18,554 & 17,493 & 21,052 & 22,619 & 20,507 \\
USA & 8,032 & 7,861 & 9,700 & 9,846 & 9,955 & 10,481 \\
Taiwan & 2,749 & 4,171 & 6,126 & 11,163 & 23,309 & 31,246 \\
Europe & 1,527 & 1,722 & 2,207 & 2,508 & 2,870 & 1,787 \\
Philippines & 4,032 & 3,622 & 3,554 & 3,199 & 3,838 & 3,344 \\
South Korea & na & na & 1,221 & 1,823 & 2,074 & 1,782 \\
Australia/ & & & & & & \\
$\quad$ New Zealand & 769 & 558 & 498 & 692 & 1,312 & 618 \\
Others & 1,987 & 4,009 & 3,274 & 2,946 & 3,353 & 3,974 \\
Total & 36,117 & 40,497 & 44,073 & 53,229 & 69,330 & 73,719 \\
\hline
\end{tabular}

Source: Palau Visitors Authority.

Note $:$ na $=$ not available . 
(I) Purpose of Tourism: Some 67 percent of Japanese and 55 percent of Americans mentioned "diving" as the purpose of their visit, while 56 percent of Taiwanese mentioned "general tourism" (ie, recreational tourism packaged by tour agents) as their main reason for coming.

(2) Length of Stay: Eighty-seven percent of Taiwanese tourists stayed for a period of three or four nights, 47 percent of the Japanese stayed three or four nights, but 39 percent of the Japanese stayed for five or six nights. Americans and Europeans stayed longer: an average of 7.57 nights and 8.5 I nights respectively. They stayed longer because the long trip to faraway Palau is seen as a once-in-a-lifetime event, while it takes only three hours by direct flight for Taiwanese, and five hours for Japanese flying via Guam.

(3) Types of Tour: Eighty-eight percent of Taiwanese and 85 percent of Japanese tourists used package tours, but 64 percent of Americans and 89 percent of Europeans arranged their own visits.

(4) Sources of Information: Thirty-four percent of Japanese obtained information about Palau from magazines, ${ }^{1}$ while 49 percent of Taiwanese heard about Palau from travel agents. Among Americans, 32 percent got their information from family and friends.

(5) Age of Tourists: Fifty-nine percent of Japanese tourists are aged between 25 and 34, while 72 percent of Taiwanese are between 25 and 44. (Khaleghi 1996)

From the viewpoint of sustainable ecotourism, the strategy adopted by the Palauan government, the difference between Taiwanese mass or general (recreational) tourism and Japanese (and American) diving and ecotourism is important. Although Taiwanese tourists are ranked first in terms of numbers, they are not necessarily the kind of tourists that Palau wants to receive. During my stay in Palau in 1997, I often heard Palauan people complaining of the "bad manners" of the Taiwanese tourists who lack "eco-consciousness" and damage the coral reefs, an important resource in Palauan ecotourism. Palau wants to host as many tourists as possible, but clearly ecotourism is a special niche in the tourist market that is often in conflict with mass tourism.

In terms of the job market related to tourism, less than 40 percent of the tourism sector in Palau is occupied by Palauans. According to the Palau Visitors Authority's analysis, "there are very few incentives for Palauans to participate in this sector, because wages are low, training programs are 
in their infancy, and those who show initiative and entrepreneurship typically move to other countries" (PVA I997, I 5). On the other hand, 6,5 I7 foreigners resided in Palau in 1997, over half as many as the native Palauan population of about I3,000. Of this figure, Filipinos constituted the largest number with 4,II4, followed by Chinese from the People's Republic of China with I,209 (Tia Belau, I4-28 June 1997). Filipino immigrants work in the tourism sector, as well as in places such as hotels and restaurants. All the employees at the hotel where I stayed in Koror and almost all the waitresses and cooks at restaurants I visited were Filipinos. The ironic result is that often it is the Filipinos, not the Palauans, who welcome tourists to Palau.

The Palau Visitors Authority has argued that Palauan participation in the tourism labor force must not be allowed to fall below 50 percent in the short-term, and should be restored to 75 percent by the year 2000 (PVA I997, 5). Furthermore, there is the question of who gains from the tourist industry. An estimated 85 percent of the revenues are enjoyed by foreign tour operators and suppliers, particularly Japanese and Taiwanese capital. The authority stresses, therefore, the necessity to create a tourist industry that is completely operated, maintained, and controlled by Palauans at the termination of funding under the Compact of Free Association in 2009. Otherwise tourism could become a new form of economic colonialism for Palau.

\section{Japanese Tourists in Palau}

In I997, I6.8 million Japanese traveled overseas (Sorifu I998; see also Carlile, this issue). Such a large number of Japanese tourists in the international tourism market is undoubtedly due to Japan's economic power today, though there has been a slowdown because of the recent collapse of the Japanese bubble economy. ${ }^{2}$ According to the World Tourism Organization report in 1997, Japan spent 10.4 percent of the total money spent on tourism (excluding transport) in 1995, when it ranked third in the world, following Germany and the United States (Mowforth and Munt I998, 2I).

The United States is the primary destination of Japanese international tourists. Roughly 5.4 million people visited the United States in 1997. However, of the Japanese tourists who visited, approximately 2 million went to Hawai'i, I million to Guam, and about 380,000 Japanese tourists visited the Northern Mariana Islands, namely Saipan. In other words, 
the Pacific provides one of the most popular destinations for Japanese tourists. Palau belongs to this Pacific tourist zone.

How, then, is the Pacific region conceived of by Japanese tourists? The popular image of the Pacific for many Japanese is that of a "south seas paradise," with beautiful sea and sunshine where Japanese middle-class tourists can escape their busy and stressful urban lives in Japan. In the stereotypical tourist brochures, Hawai' $i$ is "a paradise full of heavenly splendor," visiting Fiji is described as "touring a small paradise," Rota is "a supreme paradise," Tahiti is "the last paradise," and so on (Akimichi I997, 244). "Paradise" is the cliché used to describe contemporary Pacific resorts, which are presented in the tourist brochures with pictures of luxury hotels, young women in swimming suits, tropical fruits, and tropical fish in the coral reefs. Under the heading "Entering the Paradise of Micronesia," a recent tourist guidebook introduced Micronesia thus:

Micronesia-it sounds relaxed: full of sunshine, coral reefs, an uninhibited island with coconut trees, an old car running on the single island road. Those who come from busy Japan are certainly fascinated by the free and easy landscapes and green surroundings. People wonder whether it is possible to stay on islands like these. It would be just like paradise listening to CD music while hearing the sounds of leaves of coconut trees trembling in the breeze. (Shimokawa 1999,2$)$

Table 3. Destinations of Japanese international tourists in 1997.

\begin{tabular}{lclc}
\hline \multicolumn{1}{c}{ Country } & Number of tourists & \multicolumn{1}{c}{ Country } & Number of tourists \\
\hline United States & $5,376,637$ & United Kingdom & 408,592 \\
South Korea & $1,602,469$ & Northern Marianas & 383,033 \\
China & $1,040,465$ & Canada & 369,654 \\
Hongkong & 913,368 & France & 355,920 \\
Taiwan & 823,203 & Philippines & 321,046 \\
Australia & 779,357 & Germany & 265,617 \\
Thailand & 728,733 & Malaysia & 249,118 \\
Singapore & 700,063 & Spain & 152,439 \\
Italy & 506,126 & New Zealand & 150,937 \\
Indonesia & 440,372 & Switzerland & 111,595 \\
\hline
\end{tabular}

Source: Sorifu (Japanese Government, Prime Minister's Office) I998, 43 
Palau is such an island paradise in Micronesia- a new niche for those bored with the mass tourism of Hawai' $i$ and Guam. With its transparent waters it has become particularly popular as a diving spot. Diving has created a new category of tourism in the Japanese market over the last ten years or so. Palau is now listed as a diving spot in the same way as Guam, Saipan, Rota, Pohnpei, Sebu, Sipadang, Bali, the Maldives, the Great Barrier Reef, Fiji, New Caledonia, Tahiti, and the Red Sea.

Although most ( 85 percent) of Japanese tourists use package tours, they do not necessarily behave as a group. Unlike the former stereotypical image of Japanese tourists marching behind the upraised flag of a tour

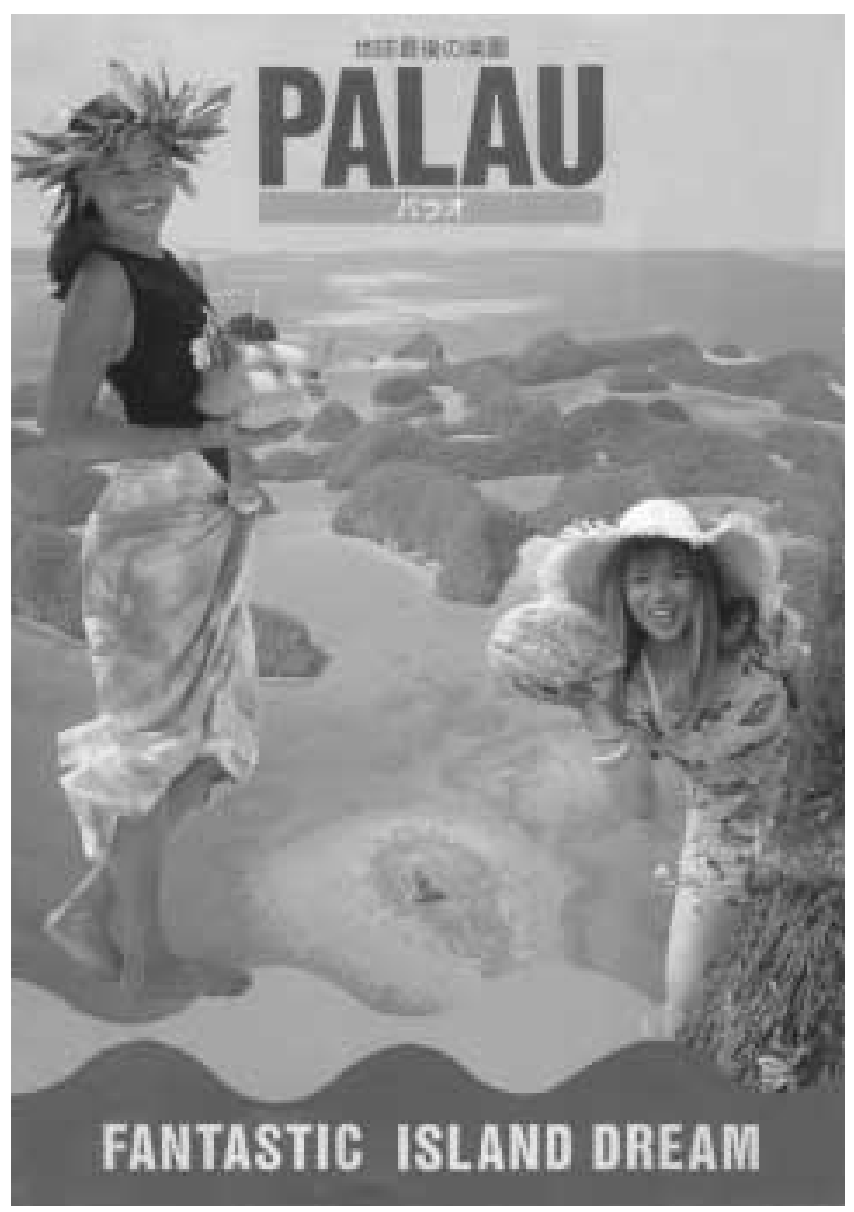

Рното г. Palau, the last paradise. (Front cover of Palau Visitors Authority brochure) 
conductor, Japanese diving tourists in Palau are very individualistic and free. ${ }^{3}$ They use package tours only for economic reasons, to get cheap tickets. Further, most of the diving tourists are repeaters. In my field research in Palau I came across a young woman who had visited Palau eight times in two-and-a-half years. She explained her fascination with diving by emphasizing that she could forget everything by going beneath the beautiful sea with coral reefs.

Apart from the divers, some Japanese tourists, mainly veterans and their families, visit Palau for memorial services. In the last stages of the Pacific War, many Japanese soldiers were killed in the battles with the United States military. Some of the fiercest battles were fought in Palau in

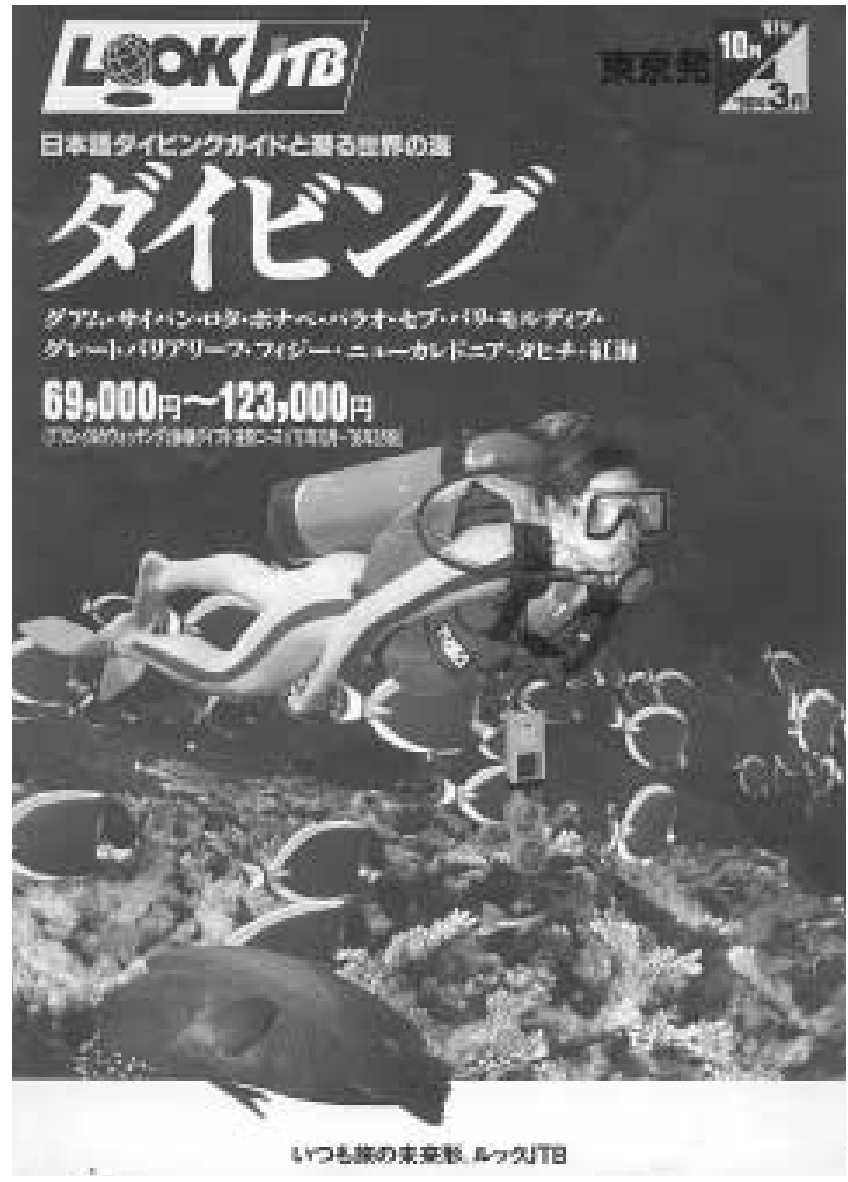

Рното 2. Diving tourism. (Front cover of Japan Tourist Bureau brochure) 
1944, particularly at Angaur and Peleliu, where some twelve thousand Japanese and eighteen hundred Americans were killed. The first attempt to excavate the bones of the deceased Japanese soldiers in the Pacific was made in I953, and memorial tourism started in the I960s as part of this activity. Some Japanese Palauan associations, such as Sakura-kai and Palau-kai, helped in arranging tours. Before the diving tourists came to Palau, memorial tourists were the major visitors from Japan. The older Japanese who visit Palau are mainly memorial tourists, though today the excavation of bones is not allowed.

During my stay in Palau I had a chance to visit Peleliu Island with a memorial tourist group from Hokkaido. On arrival at Peleliu they were welcomed by a local Japanese guide who had grown up in Palau as the child of a pioneer farmer during the Japanese colonial days and had recently returned to Palau after his retirement. They visited the commemorative monument and prayed along with a prerecorded Buddhist chant. Then they visited various memorial sites, such as the former army headquarters, abandoned tanks and cannons, Orange Beach (a famous battle site), the Peleliu Shrine, and so on.

Some tourists lived in Palau during the Japanese colonial period. In I94 I, approximately thirteen thousand Japanese resided in the town of

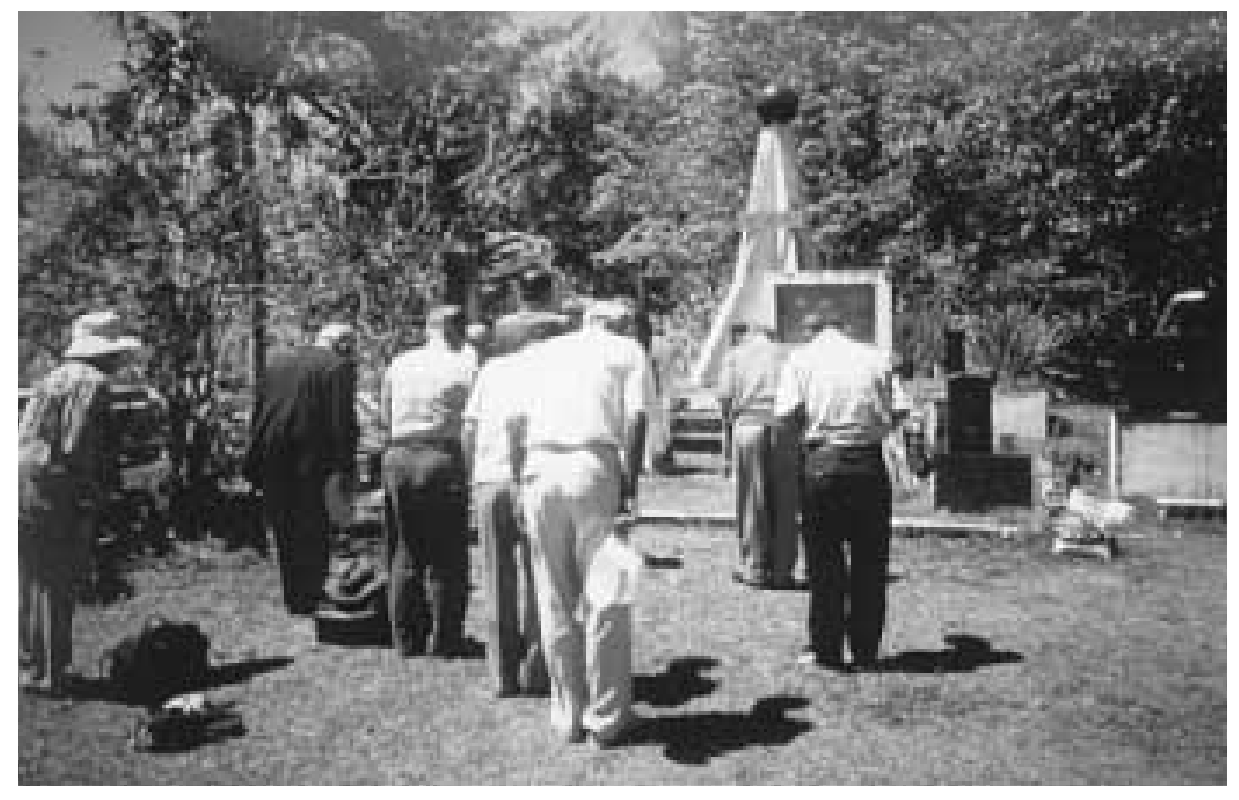

Рното 3. Memorial tourism at Peleliu. 
Koror (Uehara I990, 58). Some worked in the government sector, and others in the commercial and agricultural sectors. On Babeldaob, the largest of the Palau Islands, Japanese pioneered farming settlements such as Mizuho-mura, Asahi-mura, Yamato-mura, and Shimizu-mura. Former residents sometimes make sentimental journeys to renew what Tomiyama, in his paper on Japanese colonialism in Micronesia, called "memories of empire" (1997, 199). Among them are Japanese people who returned to Palau after their retirement to open restaurants or to work in the tourism sector. The Japanese guide on Peleliu is such a person.

Younger Japanese who come to Palau only for the diving are often unaware that Palau was once a Japanese colony. In addition, the tourist

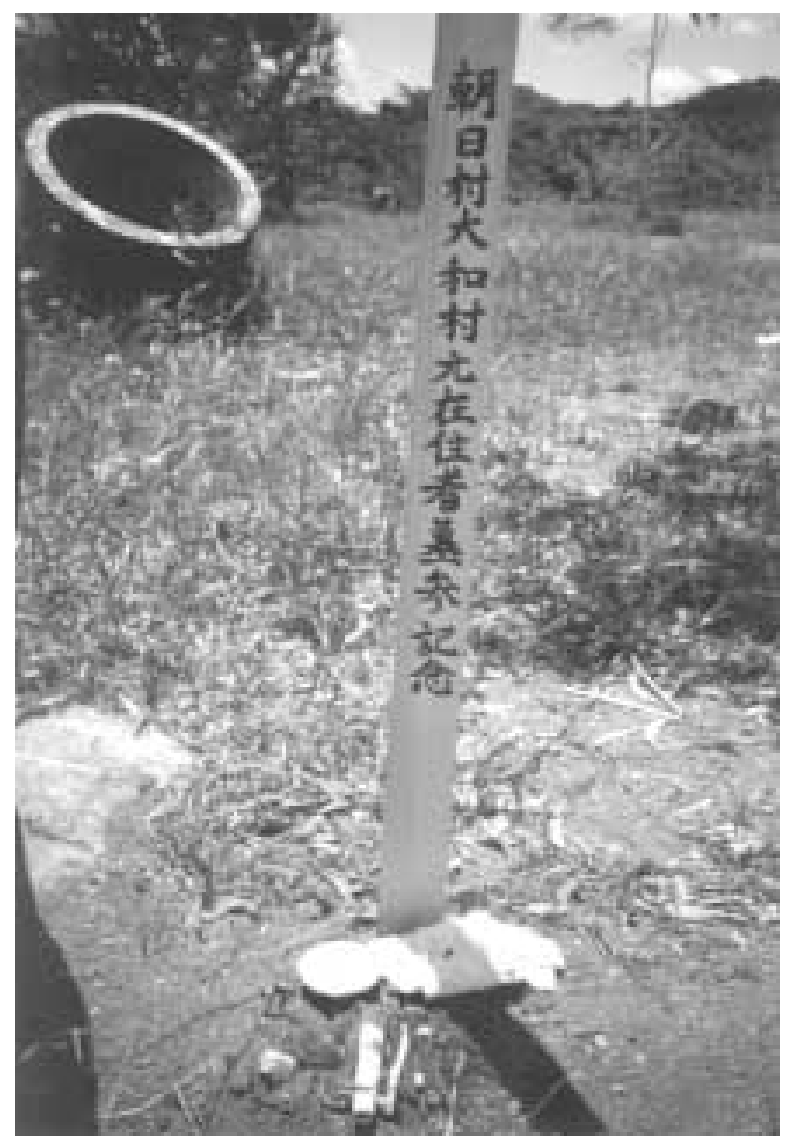

Рното 4. Memorial tourism at Asahi-mura and Yamato-mura, former Japanese settlements on Babeldaob. 
brochures and guidebooks disregard old colonial memories by describing Palau as, for instance, "Rock Islands on the blue seas. Flower gardens of coral reefs surrounding the Islands. Just by coming into contact with the landscape you can refresh yourself" (Japan Tourist Bureau Pocket Guide, Saipan-Micronesia 1997, 7). The current Palauan emphasis on nature and marine tourism, therefore, seems to conceal the colonial history. However, to fully understand the Japanese touristic encounter with Palau, one must review the history of Japanese colonization of "the South."

Japanese Colonization of the South and the Formation of Its Popular IMAGE

According to Tomoya Akimichi (1997), Japanese involvement in the Pacific began in the I 860 s, although there had been previous accidental contacts between Pacific Islanders and Japanese fishermen. Japanese labor emigration to Hawai'i started in 1868 , the first year of the Meiji period. In I 875 Japan declared its control over the Ogasawara (Bonin) Islands. Because of increasing population and limited resources at home, the Japanese government at that time adopted a policy of overseas advancement.

In the I880s and I89os, a group of ideologues advocated "Southern Advancement" or nanshinron. Among them was Tsunenori Suzuki, who went to the Marshall Islands in I 880 on the orders of the then foreign minister, Kaoru Inoue, to investigate the murder of a Japanese by the local people. In 1892 he published a book called Nan'yō Tanken Jikki (A Record of Exploration in the Southern Seas) based on this journey. ${ }^{4}$ Shigetaka Shiga was another important figure who wrote Nan'yō Jijo (Report on the Southern Seas) in I887, after his journey to the Pacific Islands and Australia. Ukichi Taguchi wrote Nan'yō Keiryakuron (On Development in the Southern Seas) and established the trading company, Nanto Shokai in I 890 . Yosaburo Takekoshi further popularized the image of the southern regions by publishing his Nangokuki (On Southern Countries) in I9Io, based on his journey to what is now Southeast Asia-Shanghai, Hongkong, Singapore, Java, Sumatra, and French Indochina-in the previous year.

Toru Yano, a political scientist, has examined southern expansionism through an analysis of the discourses of these ideologues (I975). According to him, these accounts emphasized the underdeveloped, political backwardness of the southern regions, and suggested that their development 
should be the task of Japan. Importantly, Shiga presented the Nan'yō, which literally means "the South Seas," as another "new world" that belonged neither to the East nor the West, the two civilized worlds known to Japan. Japan's advancement into the southern regions can be seen as a method of establishing itself as a civilized country compared to the underdeveloped and backward southern regions. In this sense it was linked with the expansionism adopted in response to changing international circumstances after the Meiji Restoration.

Colonial expansion into the South started with Taiwan in 1895 , Micronesia in I9I9 (Palau had been under Japanese occupation since I9I4), and reached as far as Southeast Asia in I94I. This vast region of the Pacific and Southeast Asia was then called Nan'yo (the South Seas) or Nanpo (the Southern Regions). After the Japanese occupation of Micronesia in I9I9 under a League of Nations mandate, and especially after the Nan'yō Kohatsu (South Seas Development Company, established in I920) successfully started sugar plantations in Saipan and Tinian, many Japanese people migrated to the region. The number increased every year. Nan'yocho, the Japanese colonial government of the South Seas, was established in Koror, Palau, in 1922. In I933, 30,670 Japanese were residing in Micronesia (the total population was 80,884 ). In Tinian, for instance, of the 7,554 total residents, 5,538 were Japanese.

After 1935, as advancement into the southern region became part of a policy of imperial expansionism to form the Daitoa Kyoeken or Greater East Asian Co-Prosperity Sphere, the Japanese population in the Pacific increased even more. In I936 Nan'yō Takushoku, a regional planning agency, was established under governmental control. Japanese residents increased to 77,000 in 1940 , then to 96,000 in 1942. In Palau where Nan'yo-cho was located, there were I3,000 Japanese by I94I. Big development companies opened branches, and a government Shinto shrine, Nan'yō Jinja, was established in I940 with a ceremony in honor of Amaterasu Omikai, the Japanese Sun Deity. The Japanization of Micronesia thus proceeded.

The popular image of the South for the Japanese was formed through these historical processes. According to Minato Kawamura, a specialist in modern Japanese literature, one popular image can be observed in a cartoon series for boys called Boken Dankichi (The Adventurous Dankichi; Kawamura I993). Drawn by Keizo Shimada, this was a very popular serial cartoon in Shonen Kurabu (Boys' Club) magazine, from I933 to I939. It related the adventures of Dankichi, a heroic boy, who drifts to an island 
called Banjinto (Savage Island) somewhere in the tropical South after falling asleep on his fishing boat. He later becomes the king of this savage island of cannibals with the assistance of Kariko, the clever mouse. Dankichi is drawn with white skin, a grass skirt, and a crown on his head, while his followers in the South are dark skinned and called kuronbo (nigger). These black people have numbers on the front of their bodies and look like the Western stereotypical image of Africans. Animals like lions, elephants, and giraffes live on Dankichi's island, although the island was modeled after the Nan'yo Gunto, then Japanese Micronesia. ${ }^{5}$ Interestingly, Dankichi always wears a watch on his wrist and shoes on his feet, symbolizing his membership of the civilized world.

Another example is a popular song called Shucho no Musume (Daughter of a Chief), composed and written by Ichimatsu Ishida. The song became a great hit in I930 on the radio and on disk, even though it had been composed in the early I920s (Kawamura I994, 88). The lyrics go like this:

\section{Watashi no lava-san shucho no musume Iiro wa kuroi ga Nan'yō ja bijin Sekidochokka Marsharu Gunto Yashi no kokagede tekuteku odoru}

My sweetheart is the daughter of a village chief She's pretty dark, but in the South Seas, she's a beauty In the Marshall Islands, below the equator [sic] She dances slowly in the shade of the palm trees (Peattie 1988, 216)

According to Peattie, "Micronesia was viewed as a distant paradise, conceived as being literally in the South Pacific, and inhabited by primitive peoples not much different than "savages" anywhere-naked, ignorant, sensuous, and dark skinned. . . . After arriving in Micronesia, most colonists, who usually settled in one of the larger Japanese communities in the islands, had little opportunity to alter this stereotype, since they made scant effort to break out of their colonial boundaries" (Peattie I988, 2I6-2I7).

Further, Peattie noted a distinct difference between Western and Japanese residential areas in the colonial landscapes. In the Japanese areas one could not find the colonial luxuries found in the Western colonies, partly because Japanese colonial society did not have well-defined classes, and partly because the Japanese did not like to display wealth and privilege to 
others. In other words, there was no distinct social and economic elite in Japanese colonial society (Peattie I996, 275). Japanese migrants to the South Seas mostly came from the poorer classes and regions of Japan, especially from Okinawa, ${ }^{6}$ and Koreans were included as well. These facts made Japanese colonialism in Micronesia unique in colonial history. In Japanese Micronesia, it was not a small elite colonial minority that exploited the local majority. Rather, the colony was developed by poor migrants, the majority of whom lived without much contact with the local people.

However, a colonial social hierarchy did of course exist. On top were Japanese who came from mainland Japan, with Okinawans in the middle, and Koreans below them. At the bottom were the Islanders, who were classified as tomin. Tomiyama examined how the tomin were categorized, represented, and-importantly_ “diagnosed" and "treated" by the Japanese scientists of the Tropical Zone, such as ethnologists, anthropologists, medical doctors, population scientists, colonial policy specialists, development economists, and so on (1997). As was the case in popular representations of the South, the tomin were represented and designated as "backward" and "lazy," and therefore, in need of being "treated" and "developed."

This Japanese scientists' view of the South, together with the popular ideas examined earlier, could be regarded as a Japanese kind of orientalism. According to Kang Sang-Jung (I996, 86), "Japanese orientalism" can be defined as being motivated by a desire to avoid Western imperialistic violence and to use Japan's own hegemonic power in the Asian and Pacific regions. ${ }^{7}$ Japan needed the primitive and backward South in order to feel advanced and civilized itself.

The national motto of datsua nyuo (dissociating from Asia, joining with the West), modern Japan's long-cherished wish, was achieved not only by modernizing, civilizing and Westernizing itself but also by seeing other Asian and Pacific regions as primitive and backward. In other words, Japan's civilization and enlightenment entailed regarding regions of the Asia and Pacific regions which shared the same cultural roots as relatively primitive and savage. (Kawamura I993, I20)

Dual processes of "orientalizing" Asian and Pacific regions and "de-orientalizing" Japan from them proceeded simultaneously. Due to Japan's peculiar modernity, Japanese orientalism is different from Western orientalism. The Japanese stance toward the Nan'yō is ambiguous in terms of 
cultural distance: it is sometimes assumed to be "far," a remote, primitive place, and sometimes "near," the cradle of Japanese people who share the same racial and cultural traits. ${ }^{8}$ The Japanese image of the South was constructed on the basis of this ambiguous consciousness.

\section{Hisakatsu Hijikata and the Storyboard}

As an ardent admirer of Gauguin as well as a man with interests in primitive cultures through his reading of books on ethnology and archaeology, Hijikata had a strong interest in the South (Hijikata I99I, I90-I9I). In I929 he left Tokyo for Palau, following a long-cherished desire. After arriving in Palau, he soon started to teach wood carving to the Islanders at the kogakko (public schools) and at a handicraft school for local carpenters, as a part-time employee at the Nan'yo-cho. He became particularly interested in the bai (meetinghouse), which had colored storyboards on which various pictures of gods, humans, birds, fish, and plants were carved. In his teaching, therefore, Hijikata encouraged his pupils to learn about and make storyboards.

As James Nason has discussed, this made Palau a major exception in the

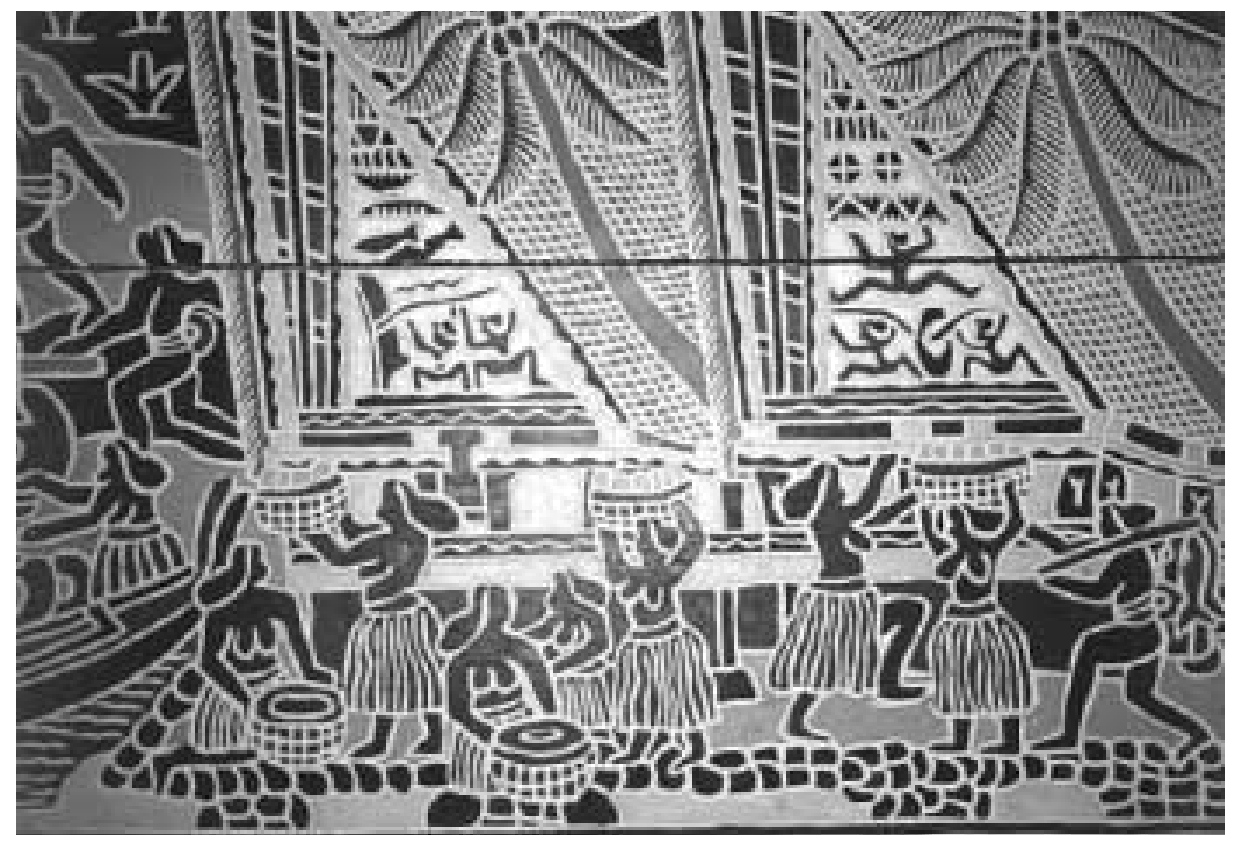

Рното 5. Storyboard in the style of Ngiraibuuch. 
general decline of traditional craft production in Micronesia. The storyboards were small rectangular wooden boards on which various motifs from stories were carved and painted. They were called itabori in Japanese and bought by Japanese residents in Palau and occasional tourists from Japan. According to Nason, new motifs were introduced for a variety of other wood carvings, such as naturalistic rooster-shaped bowls, and some support was provided for the making of jewelry from shell and turtleshell (Nason 1984, 434). The new handicrafts that were invented during the Japanese colonial days play an important role in Palau tourism today. ${ }^{9}$

Further, according to Earl Wesley Jernigan, in the I960s during the American occupation rapid changes were observed in storyboard styles (1973, I68). They were seen in the works of Ngiraibuuch, Osiik, Sbal, and Bernardino Rduloal. Of these storyboard carvers, Ngiraibuuch, Osiik, and Sbal were pupils of Hijikata in their teens in the I930s. Jernigan pointed out that one of the most important differences between the traditional narrative style and the modern storyboard styles is the representation of spatial depth in the latter (I973, 266). This was the result of the artists learning about western perspective, having been taught to draw by Japanese artists during the Japanese colonial time.

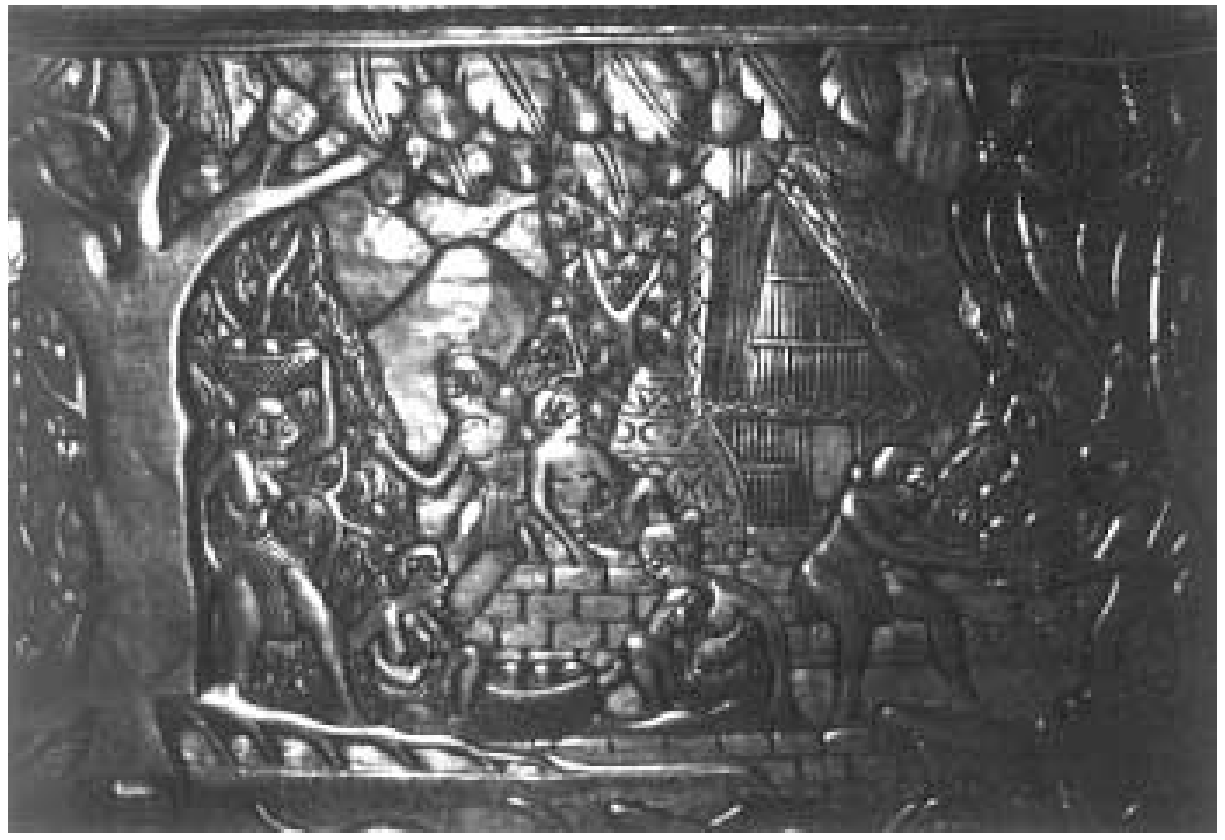

Рното 6. Storyboard in the style of Baris. 
Another interesting figure was Baris Sylvester, a Palauan who began to concentrate on storyboard making during his time in jail. "Baris' work is popular with many Americans, perhaps because it has a rustic appearance and conveys a strong sense of carved wood. It looks 'primitive' in the same sense that the work of the American painter Grandma Moses looks primitive and almost 'baroque' crowding of his compositions gives the entire surface of the board an active and rich texture. Many tourists who are unfamiliar with the arts of Palau perceive Baris' work as more authentic or traditional, though in fact the reverse is true" (Jernigan I973, 248-250).

Under the influence of Baris, the jail became one of the most active centers of storyboard making in Palau. Tourists could go to the jail to order and buy storyboards from jail carvers. Even now, storyboards are still made in jail, though not sold there anymore. In this way, the jail style originated by Baris now forms the mainstream of the storyboards for tourists. Further, according to Margo Vitarelli, an American artist born and raised in Palau, the number of stories depicted on the storyboards has declined compared with former times. Only a few famous stories of breadfruit and turtles, which are easily understandable to tourists, are now included. The storyboards thus have become tourist art.

\section{The Tourist Encounter}

One of the main tasks of the anthropology of tourism is to observe and analyze the interaction of the tourists and the host society (see Smith I989). What happens, then, in the tourist encounter between Japan and Palau?

Given the colonial connection, one might assume that Japanese tourism in Palau would have a unique character. A direct example is memorial tourism. For tourists of this kind Palau is a place of colonial memories, particularly of wartime experiences. The beautiful Palauan seas may remind them of the bloody battle that turned the beach orange (the famous Orange Beach on Peleliu). But this type of tourism has become less and less significant, as the people concerned are getting older. It is estimated that memorial tourism now constitutes less than 5 percent of total tourism in Palau. On the other hand, the younger Japanese tourists are rarely interested in colonial history.

However, the stereotypical Japanese perception of the South in colonial days continues to be reproduced today, even in postcolonial tourist bro- 
chures and guidebooks. These emphasize free and easy relaxation, the opposite of the busy and highly developed urban life in Japan, using words such as nonki (easy), nonbiri (unhurriedly), and kiraku (optimistic). In the tourist guidebook for Micronesia mentioned earlier, typical tourist behavior is depicted:

Stay at a hotel located at the island whose main street is just thirty minutes walk long. Snorkeling and diving on an inhabited island during the daytime, and listening to the mysterious folk tales of the island under a lamp at night. Meet the chiefs of the island taking them gifts from Japan. These chiefs who govern the island can speak Japanese very well and are friendly. Drinking Budweiser together, we think about the harsh reality of the island. But looking up to the sky with thousands of stars, nonki [ease and comfort] is the word which fits the island. Relaxing after arriving on the islands, one can imagine living in Micronesia someday. Yes, this is a real way of life. The chiefs and villagers we met in the islands and the Japanese who moved to Micronesia taught it to us. As you see, Micronesia was a paradise. (Shimokawa 1999, 2)

For most Japanese, the South is regarded as a place which is in some ways "underdeveloped," and therefore "easygoing," though not in a negative sense. It is often viewed as a place that makes travelers feel a degree of familiarity and even nostalgia, as described in the following passage from Tio in the Southern Islands, a novel written by Natsuki Ikezawa, a contemporary Japanese novelist:

"Why do I love this place so much?" Tom [a Japanese tourist to the island] said as if he was asking himself. Then, Tomoko, his girlfriend responded: "Such places exist-places that make you feel as if you have lived just to visit them, even through you are seeing them for the first time. Places where you discover a different aspect of yourself. This is the place for you. A quiet sunlit island in the middle of the South Seas. Easygoing people surrounded by beautiful seas and coconut trees. And kind island boys. (Ikezawa I996, I44)

The South is a place that makes you feel as if you have lived and a place where you discover a different aspect of yourself. For many Japanese the South is not necessarily seen as a far, exotic place. Looking at Bali, Indonesia, Misa Matsuda suggested that Japanese tourism in the South should be analyzed not only from the perspective of exoticism but also of nostalgia (Matsuda I989, 43-45). To Westerners, Balinese culture with its barong dance (lion dance), Hindu temples, and rice terraces may look exotic, but to the Japanese the barong dance is reminiscent of the Japanese lion dance, the Hindu temples remind them of those in Kyoto and Nara, and rice terraces are quite normal in Japanese rural areas. Bali 
reminds Japanese tourists of landscapes that have vanished in present-day urban Japan. "Nostalgia" is, then, an important factor for the Japanese in relation to Bali. ${ }^{10}$ This may be the case for the Pacific as well.

Just as, culturally, the contribution of Japanese artist Hisakatsu Hijikata led to the "invention" of the storyboard, which has become a major Palauan handicraft sold to tourists, tourism may lead to the self-consciousness of a host people (compare Picard I995). In the Pacific area, Jocelyn Linnekin has examined cultural identity in relation to tourism by taking examples from Hawai'i and Sāmoa (I997). According to her, identity merchandise has become popular in Hawai'i in the I990s. The state and the tourist industry are hoping to attract a better class of tourist and revamp Hawai'i's image by offering a more "authentic" and higher quality tourist experience. Plastic hula skirts are out; respectful performances of ancient (kabiko) hula are in. ${ }^{11}$ In Sāmoa, cultural tourism takes the form of guided visits to rural villages, and the public market in Apia offers craft items to tourists, such as miniature kava bowls and outrigger canoes, coconut-leaf fans, shell necklaces, and woven pandanus leaf handbags.

In Palau extensive use is made of cultural symbols such as the bai, the traditional meetinghouse in Palauan culture. Government buildings, hotels, and even discotheques are built in the traditional style of bai. Bai motifs are drawn on license plates, stamps, and T-shirts. And storyboard motifs appear on government buildings, in artwork for sale at the airport, and on postcards. Furthermore, the Palau Visitors Authority report and action plan for sustainable development policies has proposed that there is a need for an increased contribution from Palauan culture and heritage to tourism programs and facilities (PVA I997, 44). According to the report, the islands possess many unique cultural features such as the Yapese money quarry and the stone monoliths, although there has been relatively little development of these resources, which could be a component of either culture-based tourism or an integral part of ecotourism. The development plan for Babeldaob, the largest of the Palau islands, is at issue in this regard. The Division of Cultural Affairs has been making a list of the cultural and historical sites that have the greatest potential for attracting tourists.

Last, the Palau Senior Citizen Center plays an important role in the preservation of the cultural heritage. Run by senior citizens over fifty-five years old, many of whom are konketsu (born of a Japanese father and a Palauan mother), the center has been concerned with preserving the cultural heritage by producing handicrafts and occasionally performing traditional dances. It runs a souvenir shop to sell its products. During my 
stay in Palau in March I998, the center and the Palau Visitors Authority hosted an experimental "dinner show," offering "a night of traditional fun and fare" to tourists. The dinner consisted of not only Palauan food but also Japanese food such as sashimi and sushi, and the entertainment included old Japanese popular songs as well.

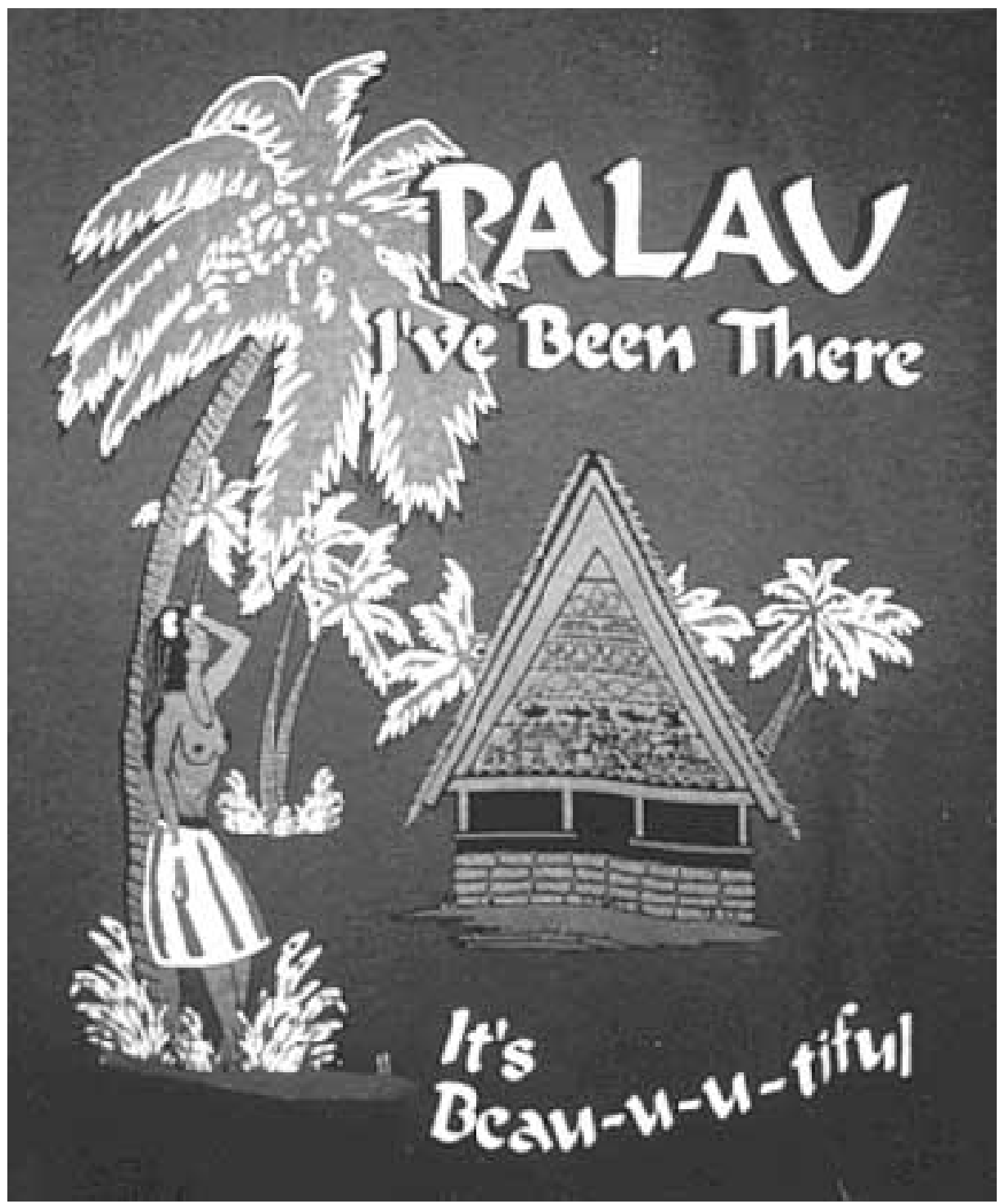

Рното 7. Palau on T-shirts. 


\section{Conclusion}

Ecotourism occupies a special niche in the tourist industry and is based on a subtle balance, not only between nature and people, but also between development and sustainability. However, according to the report of the Palau National Committee on Population and Children, Palau may have 6,000 hotel rooms by the year 2010 and be hosting 400,000 or more visitors annually (CoPopChi I997, 2). Further, the report estimates that the total population in the year 2010 could be as high as 46,000 persons, with two-thirds of them being, perhaps surprisingly, non-Palauan. ${ }^{12}$

The most critical problem of Palauan tourism is the question of where the breaking point lies in the ecological balance of the people, the land, and the sea. Although I am not in a position to answer this question, what is clear is that if the balance is broken, Palau will be unable to sustain not only tourism but even the nation itself. The sustainability of Palauan tourism depends on this delicate ecological balance. At this point, ecotourism becomes the "ideological framing" discussed by MacCannell in the quotation at the beginning of this paper. The Palauan coral reefs are not nature itself but nature ideologically framed by tourism. "Nature" here takes on a symbolic significance within which the Palauan government, tourist agents, and tourists search for meanings and value. In this sense ecotourism is a cultural production in which nature is "staged," especially for a certain type of middle-class tourist from the rich North (see Ikeda I996).

I have examined the Japanese encounter with Palau from historical as well as contemporary perspectives. In the history of Japan's southern advancement the South was "discovered" as a new world for the Japanese that belonged to neither the East nor the West. It was a backward, underdeveloped area, the development of which was the task of Japan. In this colonialist scheme, a great migration of Japanese people to the South took place. Palau was the center of this southern expansion, because the Nan'yo-cho was located at Koror. Now in the postcolonial age the Japanese visit Palau as tourists rather than as migrants. Although some memorial tourists renew their memories of colonial days, a majority of the tourists today are young divers who often do not know the colonial history. Among them the South is seen as an easygoing and relaxing place where workaholic Japanese can take their minds off work in a timeless "paradise" to refresh themselves. It may be that a postcolonial version of "Japanese orientalism" is working in the form of tourism.

By focusing on the Japanese touristic encounter with the South, this 
paper has attempted to look at Palau as a place of interaction on the AsiaPacific frontier. In so doing, I believe it will contribute to the development of a more dynamic kind of area studies, in which one can examine the encounter of a local society with the larger modern world system.

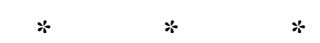

The fieldwork on which this paper is based was carried out in March 1998 as a part of the Moving Cultures project organized by the School of Hawaiian, Asian, and Pacific Studies, University of Hawai i at Mānoa, and funded by the Ford Foundation.

\section{Notes}

I Several diving magazines are published monthly in Japan. Marine Diving, published since 1968, has played an important role in promoting marine diving tourism in Japan.

2 According to Kanko Hakusho (White Paper on Tourism), in 1998 Japanese international tourists decreased by 5.9 percent compared to the previous year, reflecting the economic recession (Sorifu 1999, 33).

3 In Japan, tourism has tended to become more individualistic in the I990s, especially among the younger generation. For example, the Jalpak tours (Japan Airlines' group package tours) have been replaced by I'll tours (Japan Airlines' individual package tours), which emphasize the idea of "I will choose."

4 Jun Takayama (I995) has recently examined the book in detail and has pointed out that parts of it were plagiarized from Western literature, though the book is narrated as if these were Suzuki's own observations.

5 John Russel saw the black "primitives" drawn in Boken Dankichi as originating in Western images of black people (I99I, II). The cannibal image of the Pacific can be traced back to Tsunenori Suzuki's Nan'yo Tanken Jikki, which describes the peoples of the South Seas as primitive and very brutal, who practice cannibalism just like beasts. However, this image, too, may also be of Western origin if one considers Suzuki's plagiarism from Western literature.

6 Between 50 and 60 percent of the "Japanese" in the Nan'yo were from Okinawa and contemptuously referred to as "Japan Kanaka" (Tomiyama 1997, 215).

7 In the same book, Kang Sang-Jung examined Japanese orientalism based on his studies of Japanese colonial policy and toyoshigaku, the Japanese historical science of the Orient. On toyoshigaku, see also the book by Stefan Tanaka (1993), which inspired Kan Sang-Jung's discussion. The relationship between the Japanese historical science of the Orient and the Japanese sciences of the Tropical Zone might be interesting for further investigation.

8 Ichiro Tomiyama quoted the words of Rokuro Tanano, a doctor and chief 
of the Prevention Agency in the Ministry of Health and Welfare, written in 1942: "The Japanese race is actually well suited for life in the South Seas as the Europeans clearly are not. Our skin already exhibits a South Sea color, and the content is not so different from the South Sea races of today. A certain biologist has studied Japanese sweat glands and reported that our sweat glands are close to those of the South Sea peoples. In addition, the South Sea sunlight is not too bright for the Japanese eyes, nor do our noses stick out like those of the northern peoples. ... There would be no sense in saying that the Japanese race, which is far more inclined toward and appropriate to the south than the Europeans, cannot be active in the South Sea paradise. Physically and temperamentally, we are a South Sea people" (Tomiyama 1997, 208).

9 This sort of invention of tradition in colonialist and tourist eyes reminds me of the situation observed in Bali, Indonesia, where traditional culture, and particularly performing arts such as dances, were elaborated and refined in the r930s, under the Western "tourist gaze." The now famous kecak dance is a good example. This dance was re-invented for tourist audiences in the I930s by Walter Spies, a German artist living in Bali from 1927 to 1938 , and his Balinese collaborators. Now it has become "symbolic capital," exploitable for profit by being appropriated by the Balinese people within the economy of tourist development (Picard 1990; 1995, 55; Yamashita 1999, 37-65).

Io As I have examined elsewhere (Yamashita I999, I45-I46), it may be interesting in this context to have a look at recent tourist brochures for Bali. Emphasizing the concept of "heart" (kokoro), a brochure states that "Bali has become increasingly popular, because the island moves the visitors' hearts. Being moved, people visit Bali repeatedly. We can recover one by one the things we have forgotten in our busy urban lives in Japan by coming into contact with the Balinese people who live with their deities and nature. In so doing, we can appreciate our peaceful lives in this 'second homeland'" (I'll Jal Bali, April-September I996). Further, a women's magazine once featured an article entitled, "Looking for Healing in Bali." It said, "Both love and work are battle. It is difficult to heal yourselves while fighting. So if you feel tired with phone calls or commuter train bells, you should leave Japan for Bali where you will find transparent blue skies, pleasant breezes, wonderful incense and the nostalgic faces of the people. You can heal your bodies with a bath of yogurt, the essences of tropical flowers and natural seawater. It is a wonderful reward for your tired body. So let's cross the seas for healing in Bali" (Rinku, 8 July I996). Bali is presented as a healing place where young Japanese women can recover from the battlefields of the workplaces in Japan.

I I In the same article, Linnekin noted that today, kahiko is celebrated as an "authentic" tradition revived, even though most of the dances performed have been recently created $(1997,228)$. In other words "authenticity" is produced in the touristic context.

I 2 This could be. The report mentions the case of the Northern Marianas, 
where the population has increased from 16,000 in the early 1980 s to more than 60,000 today with virtually all of the increase due to immigration by nonindigenous people.

\section{References}

Akimichi, Tomoya

I997 Japanese Views on Oceania: Modernist Images of Paradise. In Images of Other Cultures, edited by Kenji Yoshida and John Mack, 244-249. Osaka: Nнк Service Center.

CoPopChi, Palau National Committee on Population and Children

I997 Population and Development: Toward Palau National Policy for Sustainable Human Development. Koror.

Graburn, Nelson

1989 Tourism: The Sacred Journey. In Hosts and Guests: The Anthropology of Tourism, second edition, edited by Valene Smith, 2I-36. Philadelphia: University of Pennsylvania Press.

Hijikata, Hisakatsu

I99I Hijikata Hisakatsu: Chosakushu (Hijikata Hisakatsu: Collected Works), volume 6. Tokyo: San'ichi shobo.

Ikeda, Mitsuho

I996 Kosutarika no eko-tsurizumu (Eco-tourism in Costa Rica). In Ido no Minzokushi (The Ethnography of Global Mobility). Iwanami Koza Bunkajinruigaku (Iwanami Series of Cultural Anthropology), volume 7, 6I-93. Tokyo: Iwanami shoten.

Ikezawa, Natsuki

I996 Minami no shima no Tio (Tio in the Southern Islands). Tokyo: Bungeishunju.

Jernigan, Earl Wesley

I973 Lochukle: A Palauan Art Tradition. PhD dissertation, Department of Anthropology, University of Arizona, Tucson.

Kang Sang-Jung

I996 Orientarizumu no Kanata e (Beyond Orientalism). Tokyo: Iwanami shoten.

Kawamura, Minato

I993 Taishu Orientarizumu to Ajia Ninshiki (Popular Orientalism and Japanese Perceptions of Asia). In Bunko nonakano Shokuminchi (Colonialism in Culture). Iwanami Koza Kindai Nihon no Shokuminchi (Iwanami Series of Modern Japan and Colonies), volume 7, I07-I36. Tokyo: Iwanami shoten.

1994 Nan'yo-Karafuto no Nihon Bungaku (Japanese Literature in the Southern Seas and Sakhalin). Tokyo: Chikuma shobo. 
Khaleghi, Hossein

I996 An Analysis of Tourism in Palau. Report prepared for Palau Visitors Authority. Koror: Pacific Business Center Program.

Linnekin, Jocelyn

I997 Consuming Cultures: Tourism and the Commoditization of Cultural Identity in the Island Pacific. In Tourism, Ethnicity, and the State in Asia and Pacific Societies, edited by Michel Picard and Robert E Wood, 2I 5-250. Honolulu: University of Hawai'i Press.

MacCannell, Dean

1992 Empty Meeting Grounds: The Tourist Papers. London and New York: Routledge.

Matsuda, Misa

I989 Japanese Tourists and Indonesia: Images of Self and Other in the Age of Kokusaika (Internationalization). MA thesis, Asian Studies, Australian National University, Canberra.

Moon, Okpyo

I997 Tourism and Cultural Development: Japanese and Korean Contexts. In Tourism and Cultural Development in Asia and Oceania, edited by Shinji Yamashita, Kadir H Din, and Jerry Eades, I78-193. Bangi, Malaysia: Penerbit Universiti Kebangsaan.

Mowforth, Martin, and Ian Munt

I998 Tourism and Sustainability: New Tourism in the Third World. London and New York: Routledge.

Nason, James D

I984 Tourism, Handicrafts and Ethnic Identity in Micronesia. Annals of Tourism Research I I:42 I-449.

Palau Government

1996 Palau 2020: National Master Development Plan. Revised Draft Final Report. Koror.

PVA, Palau Visitors Authority

I997 Sustainable Development Policies and Action Plan: Palau. Koror: Palau Visitors Authority.

Peattie, Mark R

I988 Nan'yō: The Rise and Fall of the Japanese in Micronesia, I885-I945. Pacific Islands Monograph Series, 4. Honolulu: Center for Pacific Islands Studies and University of Hawai'i Press.

I996 Shokuminchi (Colonies). Translated by Toyomi Asano. Tokyo: Yomiurishinbunsha.

Picard, Michel

I990 "Cultural Tourism" in Bali: Cultural Performances as Tourist Attraction. Indonesia 49:576-579.

I995 Cultural Heritage and Tourist Capital: Cultural Tourism in Bali. In 
International Tourism: Identity and Change, edited by Marie-Françoise Lanfant, John B Allcock, and Edward M Burner, 44-66. London: Sage Publications.

Russel, John

I99I Race and Reflexivity: The Black Other in Contemporary Japanese Mass Culture. Cultural Anthropology 6:3-25.

Shimokawa, Yuji, editor I999 Sukininachatta Mikronesia (I Love Micronesia). Tokyo: Futabasha.

Smith, L Valene, editor I989 Hosts and Guests: The Anthropology of Tourism. Second edition. Philadelphia: University of Pennsylvania Press.

Sorifu (Japanese Government, Prime Minister's Office)

I998 Kanko Hakusho I998 (White Paper on Tourism). Tokyo: Sorifu.

I999 Kanko Hakusho I 999 (White Paper on Tourism). Tokyo: Sorifu.

Takayama, Jun

1995 Nankai no Daitankenka Suzuki Tsunenori: Sono Kyozo to Jitsuzo (Suzuki Tsunenori: Between Truth and Fiction). Tokyo: San'ichi shobo.

Tanaka, Stefan

I993 Japan's Orient: Reading Pasts into History. Berkeley: University of California Press.

Tia Belau. Koror. Fortnightly newspaper.

Tomiyama, Ichiro

I997 Colonialism and the Science of the Tropical Zone. In Formation of Colonial Modernity in East Asia, edited by Tanie Barlow, I99-22I. Durham, NC: Duke University Press.

Uehara, Shinichi

I990 Umino Rakuen Palao (Palau: A Marine Paradise). Tokyo: Aminosan. Yamashita, Shinji

I999 Bali: Kankojinruigaku no ressun (Bali: What can we learn from the anthropology of tourism?). Tokyo: University of Tokyo Press.

Yano, Toru

I975 "Nanshin" no Keifu (History of Japanese "Advancement to the South”). Tokyo: Chuokoronsha.

\section{Abstract}

This paper examines some sociocultural implications of Palauan tourism through the lens of Japanese tourists. In I997, Palau had some seventy thousand international visitors, of whom more than twenty thousand were Japanese, second only to the Taiwanese, whose visits have been increasing rapidly in recent years. After discussing the general characteristics of tourism in Palau, I investigate the Japan- 
ese way of encountering Palau, not only through contemporary tourism, but also in its historical context. Tracing the history of Japanese colonial expansion to the South, the paper pays special attention to the Japanese type of orientalism, in which Japan needed to orientalize the South as a backward and undeveloped place in order to de-orientalize Japan as an advanced and modernized country. The paper also argues that this Japanese orientalism is at work in contemporary postcolonial Pacific tourism. Analyzing the interregional interaction of Japan and Palau in this way, I explore how the Pacific is situated in the larger modern world system.

KEYWORDS: colonialism, cultural identity, Japanese orientalism, Palau, sustainable development, tourism 